\title{
Hodgkin's lymphoma characteristics in HIV- infected and uninfected patients at an urban hospital in the late combined antiretroviral era
}

\author{
Clifford Gunthel ${ }^{1}$, Marylin Adamski ${ }^{2}$, Marina Mosunjac ${ }^{3}$, Minh Ly Nguyen ${ }^{1 *}$ \\ From 13th International Conference on Malignancies in AIDS and Other Acquired Immunodeficiencies \\ (ICMAOI) \\ Bethesda, MD, USA. 7-8 November 2011
}

\section{Background}

As combined antiretroviral therapy has allowed patients infected with HIV to survive longer due to improved immunity, increasing incidences of non-AIDS associated malignancies as well as chronic comorbidities are reported. One of the more commonly reported nonAIDS associated cancers is Hodgkin's lymphoma (HL) [1]. We report our experience of HL among HIVinfected and uninfected patients.

\section{Methods}

Grady Health System (GHS) provides care to the majority of the urban indigent population of Atlanta. Patients who were diagnosed with HL between January 2000 and June 2011were identified from the GHS pathology records and the GHS cancer registry. Clinic charts and medical records were reviewed. Patients' demographics, CD4 counts, HIV viral load, HIV and HL treatment and outcomes were recorded.

\section{Results}

During the study period, 95 patients were diagnosed with HL (26\% HIV-, 30\% HIV+ and 43\% HIV status unknown). The characteristics are displayed in Table 1.

Among the HIV+ patients, at time of HL diagnosis, the median Cd4 at time of HL diagnosis was 95(8-865) cells $/ \mathrm{mm}^{3}$, and $3(10 \%)$ are on cART .The median time from HIV diagnosis to HL diagnosis is 2 years $(0-20)$.
Table 1 Characteristics of HL in HIV- and HIV + patients

\begin{tabular}{lll}
\hline & HIV- & HIV+ \\
\hline $\mathrm{N}$ & 25 & 29 \\
$\mathrm{M}: \mathrm{F}$ & $16: 9$ & $22: 7$ \\
Race (black:other) & $20: 5$ & $25: 4$ \\
Median age (range) & $33(19-52)$ & $40(22-54)$ \\
Stage (I-II versus III-IV) & $5: 9$ & $2: 19$ \\
B symptoms & 4 & 5 \\
Diagnosis made solely by bone marrow biopsy & 0 & 3 \\
Morphology NS/LR versus MC/LD & $12: 5$ & $9: 2$ \\
One year survival & $76 \%$ & $45 \%$ \\
\hline
\end{tabular}

\section{Conclusions}

In the current cART era, in our institution, HL in HIV+ patients is more likely to present with advanced disease (65\% with stage III/IV). Interestingly, in $3 \mathrm{HIV}+$ patients, HL was diagnosed solely by bone marrow biopsy. Despite the availability of cART, patients are not accessing care. This may account for the poor one-year survival among HIV+ patients with HL.

\section{Acknowledgement}

This work was facilitated by the Center for AIDS Research at Emory University (P30 Al050409).

\section{Author details}

${ }^{1}$ Division of Infectious Diseases, Emory University School of Medicine, Atlanta, GA, USA. ${ }^{2}$ Infectious Disease Program, Grady Health System, Atlanta, GA, USA. 'ㄹepartment of Pathology, Emory University School of Medicine, Atlanta, GA, USA.

Published: 19 April 2012

\footnotetext{
* Correspondence: mnguye2@emory.edu

'Division of Infectious Diseases, Emory University School of Medicine, Atlanta, GA, USA

Full list of author information is available at the end of the article
} 


\section{Reference}

1. Spina M, Carbone A, Gloghini A, Serraino D, Berretta M, Tirelli U: Hodgkin's disease in patients with HIV infection. Adv Hematol 2011, pii:402682, Epub 2010 Sep 23.

doi:10.1186/1750-9378-7-S1-P26

Cite this article as: Gunthel et al:: Hodgkin's lymphoma characteristics in HIV-infected and uninfected patients at an urban hospital in the late combined antiretroviral era. Infectious Agents and Cancer 2012 7(Suppl 1): P26.

Submit your next manuscript to BioMed Central and take full advantage of:

- Convenient online submission

- Thorough peer review

- No space constraints or color figure charges

- Immediate publication on acceptance

- Inclusion in PubMed, CAS, Scopus and Google Scholar

- Research which is freely available for redistribution 